\title{
POVERTY AND WEALTH IN THE POLISH CINEMATOGRAPHY 1945-1989
}

This article is devoted to poverty and wealth presented in fiction films - both cinema and television - directed in the times of the Polish People's Republic. Poverty and wealth shown intentionally and unintentionally in these films manifest themselves in many ways. If we want to learn anything about wealth of the society shown in a given movie, a critical approach must be applied.

Keywords: poverty, wealth, Polish cinematography, Polish People's Republic, visual culture, visual history.

doi:10.2478/sho-2014-0004

Usually when we watch a contemporary film (both fiction and documentary), we can accurately recognize the financial status of the people we see on the screen. However, if we were not born when the film was created, or were too young to remember much, then it is sometimes difficult for us to decide whether the people we are watching are poor or rich. Poverty and wealth are fairly relative categories. A middle-class character in an old film might look like a beggar to us watching it now. On the other hand, a representative of a lower class but from a wealthy country in prosperous times, can appear well-to-do by viewers in poorer countries. At any rate, should we wish to define how rich society is based solely on films, we must remain cautious. It does not mean, however, that films cannot be used for that purpose. On the contrary, when we use them properly they can serve that purpose very well.

If we want to learn anything about wealth of the society shown in a given movie, a critical approach must be applied. Recently there have been 
many publications on the methods of using film and visual sources ${ }^{1}$. There is no room to cover all the debates and give account of all the conclusions in this short essay. However for the purpose of the essay, it is necessary to refer to at least some of them. It is vital to cover film genres and their grasp of reality. Some of the genres want to copy reality, for others reality is just a starting point, an object of free interpretation. As we can easily assume, we can learn more about the economic condition of society using the first type. We should remember though that a film directed in a realistic manner might be dependent not only on the reality it is supposed to reflect. It is also influenced by the director's artistic concepts and beliefs, and the wishes of the producer. The latter can often be dominating. Hence, finding out "what the reality was" can require some complicated interpretative work. Furthermore, in most cases using film sources will not be enough, hence the need to take into account other sources.

This article is devoted to poverty and wealth presented in fiction films both cinema and television - directed in the times of the Polish People's Republic. Poverty and wealth shown intentionally and unintentionally in these films manifest themselves in a plethora of ways. Analysing all of them would require a vast study. In this article, I solely intend to reflect upon the content of the films to research the titular subject.

First of all, we should remember that the Polish People's Republic was a socialist state. Therefore, all men were supposed to be equal, since the needs of every citizen were to be satisfied by the state. Of course, although cinematography is an art, it was also part of government-controlled media system.

In film, although a positive character is usually neither rich, nor poor, he does not have any significant financial troubles. He or she might experience some financial difficulties, but this is a temporary state that requires short-term saving. If a character does have money, but there are problems with supply, then he or she must be patient and wait till the goods are available. In films from as early as the period of socialist realism (19491955), positive characters - party activists, work leaders, young workers - did not manifest any dissatisfaction with their financial situation. It is evident, for example, in L. Buczkowski's film Przygoda na Mariensztacie (1954). In the film, Warsaw, destroyed during the war, is being rebuilt by young bricklayers, both male and female. They do not mind living in

${ }^{1}$ P. Burke, Naoczność. Materialy wizualne jako świadectwo historyczne; Kraków 2012; D. Skotarczak, Historia wizualna, Poznań 2012, p. 34-44. 
workers' hostels because either in the course of their work they will also get their own flats, or some of them already got them. Two TV series directed by Jerzy Gruza, Wojna Domowa (1965) and Being Forty (1974-1975, 1977), present two average middle-class families living during the terms of office of the two First Secretaries, Gomułka and Gierek, respectively. Both families have their own troubles, but they do not complain about their financial status. Working in a national company means they have enough to meet all their material needs. This provokes the question: to what extent do all these average characters - average also in terms of their finances reflect the reality of the time? Surely people like them did live in Poland back then. In the 1970s there were engineers who, just like Karwowski from Being Forty, had a three-room flat in an apartment block, Fiat 126p and a city garden. However, let us consider: how many were richer and how many were poorer? We cannot determine that based solely on films, but films can surely help us understand their situation.

When it comes to poverty, there should be none in a socialist state, because socialism is supposed to solve this problem once and for all. So, films presenting the socialist society should show no signs of poverty. And yet, when we watch a film directed back then, we can actually see quite a lot of poverty. Limits to the size of this article do not allow me to study the problem of the individual, various manifestations of poverty in films in detail. I will only point out to the presence of the problem in some films.

Filmmakers were not embarrassed to portray poverty which had resulted from the capitalist system during the interwar period. After all, socialist authorities were not to blame - they fought against that kind of poverty. This type of poverty is shown in films of socialist realism, especially those that are set in rural areas (Jasne Eany, 1947, directed by E. Cękalski; The Village Mill, 1951, directed by J. Kawalerowicz and K. Sumerski, Sprawa Konia, 1952, directed by E. Poleska; Trudna Miłość, 1954, directed by S. Różewicz). The characters, the poor are poor because they have no land of their own, and hence they have to work for the rich who cruelly exploit them. Promoting this thesis, not only in films, was supposed to persuade the peasants to relinquish their land to collective farms - kolkhoz ${ }^{2}$. Images of poverty serve propaganda, which undermines their credibility. However, it cannot be ruled out that, to some extent, they did show some aspects the rural life.

2 D. Jarosz, Polityka wladz komunistycznych w Polsce w latach 1948-1956 a chtopi, Warszawa 1998, p. 56-59. 
But films from the period also show poverty that is the result of the actions of the current, socialist authorities. This was possible in moments of crisis, when the problem of sudden pauperisation was omnipresent, living conditions worsened and people protested. Propaganda strategies back then were also in crisis, and it was possible to reveal the hidden truths. One of these truths was that the problem of poverty had not been solved yet. The crisis in the mid 1950s delivered a trend in documentary films called "the black series" (Uwaga, chuligani!, 1955, directed by J. Hoffman and E. Skórzewski; Gdzie diabet mówi dobranoc, 1956, and Ludzie z pustego obszaru, directed by K. Karabasz and W. Ślesicki; Paragraf zero, 1957, directed by B. Kosiński et al.). The black series shows Poland where most people barely make ends meet and where young people with no satisfying future, become hooligans ${ }^{3}$. This trend, drawing on some experiences of Italian neorealism, was also manifested in fiction films (Koniec nocy, 1957, directed by J. Dziedzina, P. Komorowski and W. Uszycka; Zagubione uczucia, 1957, directed by J. Zarzycki; Eighth Day of the Week, 1958, premiere 1983, directed by A. Ford). We should also note that the authorities allowed this critical approach only for a short period of time, and then an appropriate regulation in 1960 put an end to it $^{4}$. A lot of films were directed in a reactionary manner to the crisis in the beginning of the 1980s (A Lonely Woman, 1981, directed by A. Holland; The Scream, 1982, directed by B. Sass; TV series Alternatywy 4, 1982, premiere 1986, directed by A. Bareja).

The most interesting visions of poverty in the Polish People's Republic are probably those which were created with no ulterior motives. In an attempt to recreate the reality, creators also involuntarily recreated what undoubtedly says a lot about the low economic status of the society. One of the first post-war films (directed in 1948, premiered - 1949), a comedy called Treasure (directed by L. Buczkowski), showed tragic housing problems in Warsaw at the time. This film took up the problem that kept appearing until 1989, the problem that was never solved. In many films we can see people struggling in terrible conditions, in run-downs, sublet rooms or in hostels (e.g. Eve Wants to Sleep, 1957, directed by T. Chmielewski; Szczéściarz Antoni, 1960, directed by H. Bielińska and W. Haupe; Pieczone gołabki, 1966, directed by T. Chmielewski; Mały, 1970, directed by J. Dziedzina;

${ }^{3}$ M. Jazdon, Czarne filmy posiwialy. "Czarna seria” polskiego dokumentu, [in:] M. Hendrykowska (Ed.), Widziane po latach. Analizy i interpretacje filmu polskiego, Poznan 2000, p. 47-59.

${ }^{4}$ Uchwata Sekretariatu K C w sprawie kinematografii, [in:] T. Miczka (Ed.), Syndrom konformizmu? Kino polskie lat sześćdziesiatych, Katowice 1994, p. 27-34. 
Kłopotliwy gosc, 1971, directed by J. Ziarnik; A Junglebook of Regulations, 1974, directed by S. Bareja; Filip z konopi, 1981, premiere 1983, directed by J. Gębski; Alternatywy 4). Usually in these films people do not wring their hands in despair over the situation they were forced to live in. They might worry about some inconveniences, but still, these were not even treated as something extraordinary. A lot of films also registered the severe problem of alcoholism, a social ill that was quite serious back then ${ }^{5}$. Most often it was treated as something culturally specific, although sometimes the social background of this problem is also shown (Pętla, 1958, directed by W. J. Has; Nie będę cię kochać, 1974, directed by J. Nasfeter).

It is also worth investigating the films which portray some items as the object of desire: the ball in Zagubione uczucia, the bicycle in Mate dramaty (1960, directed by J.Nasfeter), better clothes in Kolorowe Pńczochy (1962, directed by J. Nasfeter). In the abovementioned films these items are desired by children, whose parents (despite working in national companies) cannot afford to buy them.

Films from the period also showed wealth. And here, just like when discussing the problem of poverty, we must remain reserved - in theory there was no room for wealth in the egalitarian, socialist society. Furthermore, this article does not discuss the details of the problem.

Rich men shown in the films are very often representatives of the social elites from the previous era. They appear in the already mentioned film Treasure, and also in a later film, Czarci Żleb (1949, directed by T. Kański and A. Vergano). In both films the rich men try to hide their goods abroad, an action which is condemned and eventually made impossible. When it comes to rich men in rural areas, in realistic socialist films they are called kutaks. They are presented as morally revolting, and they cooperate with armed forces fighting with the new order. Both types of rich men are classified as the enemies of the people, categories created for the purposes of propaganda in the first decade of the Polish People's Republic ${ }^{6}$.

Suddenly, in the 1960s, an old aristocracy appeared on screens, sometimes even with the remnants of their old fortunes (Kryptonim "Nektar", 1963, directed by L. Jeannot; Marriage of Convenience, 1966, directed by S. Bareja). They have a lot of old-school charm; however, they are not entirely innocent, since they become embroiled in various, not entirely hon-

${ }^{5}$ K. Kosiński, Historia pijaństwa w czasach PRL. Polityka - obyczaje-szara strefa-patologie, Warszawa 2008.

${ }^{6}$ G. Pełczyński, Dziesiata muza w stroju ludowym. O wizerunkach kultury chlopskiej w kinie PRL, Poznań 2002, p. 27-28. 
est operations. Even if this picture was accurate, films do not emphasize the fact that very often the professional activity of these people was very limited.

Rich people in Polish People's Republic are also represented by private operators, the so-called prywaciarze - owners of market stands, small shops or plants. They were in a way inconsistent with the vision of the socialist state. Since they were capitalists (small but still) they should not have existed. However, the economy could not afford to give them up, especially in the face of new economic crises ${ }^{7}$. Propaganda, sometimes successfully, tried to ostracise them by creating a certain image of a private operator - greedy, unsympathetic, very often a criminal. They are portrayed like this in many films (Kryptonim "Nektar", Marriage of Convenience, Milion za Laure, 1971, directed H. Przybyl; Zlote kolo, 1971, directed by S. Wohl; Hazardzisci, 1975, directed by M. Waśkowski; Koniec sezonu na lody, 1987, directed by S. Szyszko).

Also farmers who owned private farms were an inconsistency to the system. In later films, they were no longer kulaks, known from the period of socialist realism, but relatively rich farmers still who were the subject of critique as greedy, intolerant and hypocritical (Wiano, 1963, directed by J. Łomnicki; Sprawa się rypła, 1984, directed by J. Kidawa). Sometimes people pitied them claiming they had allegedly made a mistake by not joining a collective and are now worse-off (Ziemia, 1956, directed by J. Zarzycki; Rodzina, 1975, directed by K. Wojciechowski). One way or another, there was a popular trend of presenting collective as superior to individual. We should also note that in the 1970s, due to the economic policies back then ${ }^{8}$, small private farmers were more favoured. We will not find a lot of films criticizing them.

In many films a person with money is simply a thief. In Ostatni Kurs (1963, directed by J. Batory) these are the directors who, having embezzled money, try to flee to Sweden. In Zbrodniarz $i$ Panna (1963, directed by J. Nasfeter), the owner of big money is a bank robber. These films reinforce the notion that owning big money is related to criminal activity.

We should also analyze other people with money in Poland: not Polish citizens, but emigrants visiting their old country. In an anthology film Jada Goście, Jadą (1962, directed by G. Zalewski, J. Rutkiewicz, R. Drobaczyński)

\footnotetext{
${ }^{7}$ M. Krajewski, Historia gospodarcza Polski do 1989 roku, Włocławek 2000, p. 472, 511, and 528.

8 J. Skodlarski, Zarys historii gospodarczej Polski, Łódź 2000, p. 469.
} 
relatives in Poland receive their guests from overseas with selfish ends in mind. They expect very tangible material gains from their visit. And although the emigrants also have their businesses in Poland, the film clearly states that Poland's economic status is low. In contrary, in the film Mój Stary (1962, directed by J. Nasfeter), the main character, an emigrant from France, is a man who has not achieved any financial success abroad. An attempt to open his business in Poland is also unsuccessful. Few films on the subject of Polish emigrants directed later avoided touching upon the economic issues. The exception is Bilet powrotny (1978, directed by E. and Cz. Petelski). In the 1970s when Polish emigrant companies began to emerge, discussing these issues might have seemed inappropriate.

However, after the thaw in the Polish People's Republic, it was no longer a secret that some people enjoyed a relatively high financial status. However, it only applied to people of outstanding merit, to those who played an important part in society. In Knife in the Water, the journalist had a foreign car and a yacht. Even the First Secretary, Wladyslaw Gomulka ${ }^{9}$ criticized that and accused the film of promoting consumerism and nihilism. Nonetheless, it did not stop the filmmakers from showing elites in films during their term of office. These elites were clearly better off than for example characters in Wojna Domowa. This is most notably clear in Hunting Flies (1968, directed by A. Wajda) ${ }^{10}$.

Sometimes directors, people "on a mission" - diplomats or trade representatives in the West - were so busy they did not have time to raise their own children, especially adolescents. Therefore, the children, using limitless resources of their "old folks", started leading lives that seemed inappropriate in the socialist state. This is the subject of J. Hoffman's film Ojciec. Hoffman used to be one of the creators of the black series. The theme of a spoilt brat also appears in a comedy Man-Woman Wanted (1972, directed by S. Bareja). Also the children of high-ranking officials from the film Kontrakt (1980, directed by K. Zanussi) leave much to be desired.

In the 1970s there were a lot of characters in films who had money but also had personal problems (We Have to Kill this Love, 1972, directed by J. Morgenstern; Anatomia miłości, 1972, reż. R. Załuski; Jezioro osobliwości, 1973, directed by J. Batory; Roman i Magda, 1978, directed by S. Chęciński) and even existential problems (Spirala, 1978, reż. K. Zanussi). Thus, they

${ }^{9}$ I. Rammel, “Dobranoc, ojczyzno kochana, już czas na sen...”. Komedia filmowa lat sześćdziesiatych, [in:] T. Miczka (Ed.), Syndrom konformizmu. Kino polskie lat sześćdziesiatych, Katowice 1994, p. 69.

${ }^{10}$ D. Skotarczak, Obraz społeczeństwa PRL w komedii filmowej, Poznań 2004, p. 135-136. 
quite fit the image of Poland as a country, which was prosperous and catching up with the West - an image of Poland where people did not have financial, but spiritual problems.

In the 1970s the creators of the "moral concern cinema" made a series of in-depth analyses of the social situation in Poland. One of their theses was that, in order to make a career and earn a lot of money, one must act immorally and reject the standard canon of ethical values ${ }^{11}$ (Camouflage, 1976, directed by K. Zanussi; Top Dog, 1977, directed by F. Falk; Provincial Actors, 1979, directed by A. Holland). Those who refuse to accept the norms that apply in the race for material goods, and, instead, prioritise spiritual values are simply ostracised (Constans, 1980, directed by K. Zanussi). That is why the characters from Andrzej Kondratiuk's films (Petnia, 1979; Gwiezdny pyl, 1982; Cztery pory roku, 1985) not wishing to participate in the race, flee to the rural countryside and devote themselves to the search for lost values ${ }^{12}$. The character of the adaptation of Stachura's Siekierezada (1985, directed by W. Leszczyński) voluntarily leads a vagabond life. He is not interested in any material goods and focuses himself entirely on spiritual values.

My attempt to arrange the issues concerning poverty and wealth that we come across in the films from the period of Polish People's Republic, certainly proves that a researcher interested in the economic situation of the Polish society will readily find the material in these films which complements other sources on this topic. Read critically, they can reveal what other sources cannot reveal. Even films with a clear inclination towards propaganda, which allegedly show average citizens as fully satisfied with their financial situation (although we know they were not that numerous) show limits of opportunities in the socialist state at a given time. We should also remember that there were also times of breakthroughs when it was possible to demonstrate more, also on the subject of poverty and wealth in Poland. These demonstrations in films can possibly be very credible.

Dorota Skotarczak - Professor at the Institute of History, Adam Mickiewicz University in Poznań, Chair of Visual History. Scientific interests include history of culture, visual history and visual methods in history. Recently published: Historia Wizualna [Visual History, Poznań 2013].

11 D. Dabert, Kino moralnego niepokoju, Poznań 2003, p. 110-122.

12 J. Nowakowski, Filmowa twórczość Andrzeja Kondratiuka, Poznań 1999, p. 39. 